Research CommentaRies: Food Systems Research Priorities over the NeXt 5 Years

\title{
Economic impacts of local food systems: Future research priorities
}

\author{
Jeffrey K. O’Hara, ${ }^{a} *$ Union of Concerned Scientists \\ Rich Pirog, , Michigan State University Center for Regional Food Systems
}

Submitted May 31, 2013 / Published online July 12, 2013

Citation: O’Hara, J. K., \& Pirog, R. (2013). Economic impacts of local food systems: Future research priorities. Journal of Agriculture, Food Systems, and Community Development, 3(4), 35-42.

http://dx.doi.org/10.5304/jafscd.2013.034.003

Copyright (C) 2013 by New Leaf Associates, Inc.

\begin{abstract}
The recent growth in local food markets has resulted in various local food economic impact assessments. However, drawing overarching conclusions from these studies is difficult. Data collection is challenging, and the handful of studies with transparent and well-defined methodologies have generally used data and modeling techniques with narrow geographic and market scope. While these studies have found positive regional economic impacts, the impacts have been modest, and many economic aspects of local food systems remain unexamined. To address these issues, Michigan State University's Center for Regional

\footnotetext{
a * Corresponding author: Jeffrey K. O'Hara, Agricultural Economist, Union of Concerned Scientists; $1825 \mathrm{~K}$ Street, NW Suite 800; Washington, D.C. 20006 USA; +1-202-3316944; johara@ucsusa.org

b Rich Pirog, Senior Associate Director, Michigan State University Center for Regional Food Systems; 480 Wilson Road, Room 313 (Natural Resources Building); East Lansing, Michigan 48824 USA; rspirog@msu.edu
}

Food Systems and the Union of Concerned Scientists' Food \& Environment Program hosted a meeting among economists and local food researchers in order to synthesize and translate the findings of existing studies for local food practitioners and policy-makers. In this document, we briefly review the types of studies that have been conducted, identify criteria by which the effectiveness of studies can be evaluated, and discuss future research opportunities. The collective understanding of the relationship between local foods and economic development can be enhanced through improving data collection, undertaking studies on larger geographic scales that explicitly incorporate changes in diet, quantifying other economic attributes of local food systems in addition to the number of jobs, and forming a learning community to review and critique studies of the economic, social, and environmental benefits of local food systems.

\section{Keywords}

economic development, economic impact, inputoutput model, local food, opportunity cost 


\section{Introduction}

The recent expansion of local and regional food markets has heightened interest in quantifying the extent to which they contribute to economic development. Local food sales provide localized economic impacts if farmers who sell locally are more likely to purchase intermediate inputs, labor, and capital locally. When this occurs, local food sales can result in regional economic activity that is a greater "multiple" of the initial level of sales than would otherwise have occurred. Local food markets also may provide market access and business opportunities for farmers who otherwise would not be farming.

Many types of local food economic impact assessments have been conducted in regions throughout the United States. These include studies that have examined the economic impacts of specific types of local food marketing channels, like farmers' markets or farm-to-school programs; farm-level impacts of diet changes within a state or region; and studies on larger geographic scales using advanced statistical analysis. However, drawing overarching conclusions from these studies is challenging. Some studies do not publicly document their methodology and assumptions, while others studies not published in peer-reviewed journals may or may not have had a robust review process. The handful of local food economic impact studies with well-defined methodologies have generally been undertaken at the state level with a narrow market scope. The studies have found positive regionalized net economic impacts according to metrics such as output, gross regional product, income, and jobs. However, the impacts have been modest and many economic aspects of local food production remain unexamined. Also, there is not a formal learning community established to review studies and make suggestions for improvement.

Given these existing circumstances, Michigan State University's (MSU) Center for Regional Food Systems and the Union of Concerned Scientists' (UCS) Food \& Environment Program hosted a meeting of economists and local food researchers on January 31 and February 1, 2013, in order to synthesize and translate the findings of existing studies for local food practitioners and policy- makers. The meeting attendees are listed in Appendix A. The meeting objectives were to review and synthesize the literature, identify "best practice" standards associated with quantifying the economic impacts of local food systems, prioritize critical questions that should be asked by those considering commissioning a study, and identify future research topics. The meeting outcomes were conveyed in a public webinar on May 20, 2013, with an accompanying document that summarized important due-diligence questions for those considering commissioning a local food economic impact assessment (Pirog \& O’Hara, 2013).

\section{What's Been Done?}

There are many categories of food system assessments (Freedgood, Pierce-Quiñonez, \& Meter, 2011), including food system economic impacts. In this section, we categorize three basic types of local food economic impact studies. We restrict our review to a set of quantitative studies with documented methodologies and assumptions that estimate the effect of local food sales on economic statistics, such as jobs or output. First, since establishing the overall level of local food consumption in a region is challenging (Conner, Becot, Hoffer, Kahler, Sawyer, \& Berlin, 2013), some studies have estimated the regional economic impacts of specific local food market channels. Many of these studies have focused on farmers' markets, including studies of individual farmers' markets (McCarthy \& Moon, 2012; Sadler, Clark, \& Gilliland, 2013) or a collection of farmers' markets in a state (Henneberry, Whitacre, \& Agustini, 2009; Hughes, Brown, Miller, \& McConnell, 2008; Myles \& Hood, 2010; Otto, 2010). Economic impact studies of institutional purchases of local food have examined farm-to-school programs (Gunter \& Thilmany, 2012; Tuck, Haynes, King, \& Pesch, 2010) and buy-local campaigns at farmers' markets and restaurants (Hughes \& Isengildina-Massa, 2013). A second collection of studies has examined farm-level economic impacts associated with the consumption of locally supplied fresh fruits and vegetables (Cantrell, Conner, Erickcek, \& Hamm, 2006; Conner, Knudson, Hamm, \& Peterson, 2008; Swenson, 2010; Tootelian, Mikhailitchenko, \& Varshney, 2012). These studies make assumptions 
about the supply chain through which the produce will be sold when these sales are modeled as hypothetical increases in consumption. A recent farm-level study by Schmit, Jablonski, \& Mansury (2013) measured how the production budgets of small and midsize farms that sell locally vary from other farms when calculating economic impacts.

Most of the studies in the first two classifications used input-output (I-O) models to estimate economic impacts. IMPLAN is a commonly utilized I-O modeling system since it is relatively accessible and easy to operationalize (The IMPLAN Group, 2013). I-O models estimate how sales in one particular industry impact a region's output, labor income, employment, and gross regional product based on preexisting statistical relationships between sectors in an economy (Miller \& Blair, 2009). However, the results from I$\mathrm{O}$ models are more accurate when considering smaller hypothetical changes in market activity. This is because I-O models are structured so that an expansion that occurs in one sector does not impact the relative prices of other sectors. They also assume that there are no resource constraints for inputs and that the proportion of inputs that a sector uses does not change under different levels of production.

In contrast to I-O models, price-flexible models, such as REMI or a computable general equilibrium (CGE) model, can explicitly incorporate changes in relative market prices resulting from changes in supply and demand of a particular sector. To our knowledge, only one study has utilized a price-flexible model in the context of local foods (Cantrell et al., 2006). A drawback of these models is that their results can be less transparent since the model solution is calculated by solving many equations simultaneously. This restricts the number of sectors that can be modeled.

The accuracy of any type of economic model, I-O or CGE, depends on the model's parameter values. Proxy data embedded in models have the potential to (1) be out-of-date, since models incorporate data from a variety of sources that are updated at intermittent frequencies; (2) be at a coarser resolution than the researcher's specified area of study; (3) be representative of average conditions; or (4) not be based on statistical analysis. Ideally, researchers using economic models would modify the default model parameters with data pertinent for their scenarios of interest and identify data limitations associated with the model being utilized when documenting their findings.

A third collection of recent studies have used empirical, or econometric, methods to examine local food sales at a multistate or national level, including Low \& Vogel (2011), Ahearn, Brown, Goetz, \& Liang (in press), and Ahearn \& Sterns (in press). The latter two studies found that local food sales had small macroeconomic impacts, although like many of the studies mentioned previously, they did not include retail institutional purchases of local food. An advantage of advanced statistical analysis is that if the statistical tests are well designed, the effect of local food sales on economic variables can be directly estimated. Empirical methods complement modeling efforts since they can validate hypothetical I-O studies when more extensive data becomes available over time (Brown, 2012). However, the data requirements and associated costs to undertake a well-designed empirical study are high.

\section{By What Criteria Should Existing Studies be Evaluated?}

At the meeting we used three overlapping criteria to evaluate studies. Study design is the first criteria. Basic questions that must be identified include the geographic scope of the market and the point of the supply chain at which economic impacts will be measured. Two characteristics of studies to date highlight areas for further research. First, many studies of local food markets have focused on farmers' markets and direct marketing. This may be because farmers' markets are a visible local food market, while institutional purchases of aggregated local food sales may be harder to measure since the supply chain has more intermediaries. However, local food is predominately marketed through retail institutions (Low \& Vogel, 2011). Second, many studies have used political boundaries, such as a state, to define the geographic study boundaries because political boundaries are consistent with the way economic data are organized and may also coincide with the jurisdiction of interested policy- 
makers. However, local food sales may have their greatest influence on a region's economy when there are large metropolitan regions surrounded by available farmland. Swenson (2010) is an example of a study that took this into consideration in a study of six contiguous Midwest states.

The researcher's methods were the second criteria. Obtaining accurate data is one of the greatest challenges in studying local food systems and can depend critically on the survey design. Otto (2010) found a wide discrepancy in reported farmers' market sales when surveying both consumer and vendors in Iowa, while Hughes \& Isengildina-Massa (2013) found similar estimates of farmers' market sales in South Carolina when surveying both market vendors and managers. Also, obtaining more accurate results with IMPLAN depends upon how the production function of local food farmers is stipulated, such as their relative composition of inputs and the percentage of inputs they purchase locally. Schmit, Jablonski, \& Mansury (2013) found that small farms that sell locally purchase more labor and inputs from local markets than other farms.

Interpretation was the third criteria used at the meeting. A critical issue for measuring net economic impacts entails stipulating how the "opportunity cost," which is what would have occurred in the absence of local food sales, is defined. Defining the opportunity cost, however, is not straightforward because of ambiguity with the phrase "local food." In the absence of data it may require the researcher to make arbitrary assumptions. For example:

- Does "buying local" mean consumers purchase more fresh fruits and vegetables than they would without the presence of local food? Fruits and vegetables compose $65 \%$ of food sold locally (Low \& Vogel, 2011). If so, what types of food will consumers cease purchasing? Alternately, does it imply that the same food products are being purchased but are locally sourced?

- Will there be changes to market prices or the food supply chain?
- To what extent do farmers who sell locally compete directly with other farmers for farmland and other inputs?

- If the economic impact assessment is undertaken to examine the implications of a policy intervention, such as a subsidy for nutrition incentive vouchers at farmers' markets, what is the opportunity cost of the subsidy funds?

Some studies do not quantify or acknowledge any type of opportunity cost, which is problematic. Conner et al. (2008), Hughes et al. (2008), Swenson (2010), Tuck et al. (2010), Gunter \& Thilmany (2012), and Hughes \& Isengildina-Massa (2013) all found that the regional economic impacts of local food sales were positive even when opportunity costs were explicitly incorporated.

Other interpretation challenges arise when terminology and concepts are miscommunicated. Examples include misunderstanding what an economic "multiplier" measures (an economic multiplier is the ratio of the total economic impacts in a region resulting from the sales of a particular sector relative to that sector's direct sales), whether the reported employment estimates refer to "fulltime" or "part-time" jobs, or whether economic "impacts" refer to gross or net changes in economic activity. Further, while counting the number of jobs created through public investment can be a resonant message when seeking funding, a focus by policy-makers and planners on counting jobs increases the potential that they will disregard the influence that local food sales have on other longterm priorities that contribute to social welfare, including environmental, equity, health, and selfsatisfaction objectives. In the long term, policy has a greater influence on the composition of jobs that exist in society than on the number of jobs (Johnson, 2012).

To help convey these identified concepts and criteria, discussion at the meeting focused on what planners, local economic development officials, and other local food advocates should consider before moving ahead with an economic impact study of local foods. As a consequence, one of the meeting outcomes was to create a document summarizing due diligence questions that potential 
commissioners of economic impact studies should contemplate in advance of implementing a study (Pirog \& O’Hara, 2013).

\section{Future Direction}

Research on the economic impacts of local food systems is ongoing. Organized sessions have been developed exclusively on this topic in 2013 at multiple applied economics conferences, including the Southern Regional Science Association, the Northeastern Agricultural and Resource Economics Association, and the Agricultural \& Applied Economics Association. These ongoing efforts should help promote the development of standardized, science-based methods for conducting economic impact analysis of local food systems (Thilmany, Gunter, \& Tegegne, 2013). Here, we identify suggestions for improving future research that were discussed at the 2013 meeting sponsored by MSU and UCS.

First, improving data collection is a priority. Supporting stable, adequate funding sources to establish local food data-collection initiatives and prioritizing local food research in existing agricultural research programs is needed to help research efforts that, for example, document production budgets of farmers who sell through local markets and measure institutional purchases of local food systems.

Second, there is a need for more studies on larger geographic scales. One consideration that arises when synthesizing distinct region-specific economic impact studies is that while it might be in each region's individual interest to promote local food production, they may be collectively worse off if they all implement such a policy because of diminished food export markets. Such larger-scale studies might be enriched by exploring how local food production is associated with changes in diet. Emerging evidence suggests that local food markets can promote greater consumption of fresh fruits and vegetables, two food groups that are underconsumed relative to dietary recommendations (Anderson, Bybee, Brown, McLean, Garcia, Breer, \& Schillo, 2001; Evans, Jennings, Smiley, Medina, Sharma, Rutledge, Stigler, \& Hoelscher, 2012; Freedman, Choi, Hurley, Anadu, \& Hébert, 2013; Herman, Harrison, Afifi, \& Jenks, 2008).

Third, the economic contribution of local foods could be measured using other attributes in addition to counting the number of jobs. For example, there also could be more research on the spillover effects of implementing local food markets, such as the extent to which local food markets draw shoppers to neighboring businesses or increase property values (Econsult Corporation, 2006; Lev, Brewer, \& Stephenson, 2003), foster entrepreneurship (Feenstra, Lewis, Hinrichs, Gillespie Jr., \& Hilchey, 2003; Lyson, Gillespie Jr., \& Hilchey, 1995), or promote social capital.

Fourth, a national learning community of economists, local food researchers, and others who view local food as a means to community economic development should be formed to review and critique the design, methods, and conclusions of studies that examine their social, economic, and environmental impacts. This learning community could characterize study typologies and make recommendations to increase scholarship and practice in this area of study. Examples of how such a community could operate include forming a virtual community of practice led by the Cooperative Extension System (Cooperative Extension System, 2013), as a subcommittee that encourages research and education within a professional society, or as an informal grant-funded network that meets periodically through teleconference, videoconference, and at an in-person annual meeting. 


\section{Appendix A. January 31-February 1, 2013, Meeting Participants}

Meeting organizers: Rich Pirog (Michigan State University), Jeffrey K. O’Hara (Union of Concerned Scientists), Michael W. Hamm (Michigan State University), and Ricardo Salvador (Union of Concerned Scientists)

Facilitator: Kate Clancy (food systems consultant)

Recorders: Jess Daniel (Michigan State University and FoodLab Detroit), Kate Fitzgerald (food systems consultant), and Wendy Wasserman (U.S. Department of Agriculture)

Attendees: Mary Ahearn (U.S. Department of Agriculture), James Barham (U.S. Department of Agriculture), Rebecca Dunning (The Center for Environmental Farming Systems), Shermain Hardesty (University of California, Davis), David Hughes (Clemson University), Thomas Johnson (University of Missouri-Columbia), Larry Lev (Oregon State University), Richard McCarthy (Slow Food USA), Steven R. Miller (Michigan State University), Michael H. Shuman (Cutting Edge Capital), David Swenson (Iowa State University), and Dawn Thilmany (Colorado State University) 


\section{References}

Ahearn, M., Brown, J., Goetz, S., \& Liang, K. (in press). Linkages between community focused agriculture, farm sales, and regional growth. Economic Development Quarterly.

Ahearn, M., \& Sterns, J. (in press). Direct-to-consumer sales of farm products: Farm returns and supply chains in the Southeast. Journal of Agricultural \& Applied Economics.

Anderson, J. V., Bybee, D. I., Brown, R. M., McLean, D. F., Garcia, E. M., Breer, M. L., \& Schillo, B. A. (2001). 5 a day fruit and vegetable intervention improves consumption in a low income population. Journal of the American Dietetic Association, 101(2), 195202. http://dx.doi.org/10.1016/S0002-8223(01) $\underline{00052-9}$

Brown, J. P. (2012, August). Measuring ex post economic effects: Lessons from emerging energy industries.

Presentation at the Agricultural \& Applied Economics Association Community Economics Network Section Post-conference workshop: Models for assessing regional economic impacts of agriculture and rural development efforts, Seattle. Retrieved from http://aese.psu.edu/nercrd/ presentations/seattle-aee-2013

Cantrell, P., Conner, D., Erickcek, G., \& Hamm, M. W. (2006). Eat fresh and grow jobs, Michigan. Traverse City, Michigan: Michigan Land Use Institute.

Conner, D. S., Knudson, W. A., Hamm, M. W., \& Peterson, H. C. (2008). The food system as an economic driver: Strategies and applications for Michigan. Journal of Hunger \& Environmental Nutrition, 3(4), 371-383. http://dx.doi.org/10.1080/19320240802528849

Conner, D., Becot, F., Hoffer, D., Kahler, E., Sawyer, S., \& Berlin, L. (2013). Measuring current consumption of locally grown foods in Vermont: Methods for baselines and targets. Journal of Agriculture, Food Systems, and Community Development, 3(3), 83-94.

http://dx.doi.org/10.5304/jafscd.2013.033.004

Cooperative Extension System. (2013). Retrieved from http://www.extension.org/pages/30339/ cooperatives-community-of-practice-description

Econsult Corporation. (2006). The economic impacts of supermarkets on their surrounding communities (Reinvestment Brief Issue 4). Philadelphia: The Reinvestment Fund.
Evans, A. E., Jennings, R., Smiley, A. W., Medina, J. L., Sharma, S. V., Rutledge, R., Stigler, M. H., \& Hoelscher, D. M. (2012). Introduction of farm stands in low-income communities increases fruit and vegetable among community residents. Health \& Place, 18(5), 1137-1143. http://dx.doi.org/ 10.1016/j.healthplace.2012.04.007

Feenstra, G. W., Lewis, C. C., Hinrichs, C. C., Gillespie Jr., G. W., \& Hilchey, D. (2003). Entrepreneurial outcomes and enterprise size in US retail farmers' markets. American Journal of Alternative Agriculture, 18(1), 46-55.

Freedgood, J., Pierce-Quiñonez, M., \& Meter, K. A. (2011). Emerging assessment tools to inform food system planning. Journal of Agriculture, Food Systems, and Community Development, 2(1), 83-104. http://dx.doi.org/10.5304/jafscd.2011.021.023

Freedman, D. A., Choi, S. K., Hurley, T., Anadu, E., \& Hébert, J. R. (2013). A farmers' market at a federally qualified health center improves fruit and vegetable intake among low-income diabetics. Preventive Medicine, 56(5), 288-292. http://dx.doi.org/10.1016/j.ypmed.2013.01.018

Gunter, A., \& Thilmany, D. (2012). Economic implications of farm to school for a rural Colorado community. Rural Connections, 6(2), 13-16.

Herman, D. R., Harrison, G. G., Afifi, A. A., \& Jenks, E. (2008). Effect of a targeted subsidy on intake of fruits and vegetables among low-income women in the Special Supplemental Nutrition Program for Women, Infants, and Children. American Journal of Public Health, 98(1), 98-105. http://dx.doi.org/10.2105/AJPH.2005.079418

Henneberry, S. R., Whitacre, B. E., \& Agustini, H. N. (2009). An evaluation of the economic impacts of Oklahoma farmers markets. Journal of Food Distribution Research, 40(3), 64-78.

Hughes, D. W., Brown, C., Miller, S., \& McConnell, T. (2008). Evaluating the economic impact of farmers' markets using an opportunity cost framework. Journal of Agricultural and Applied Economics, 40(1), 253-265. http://purl.umn.edu/45523

Hughes, D. W., \& Isengildina-Massa, O. (2013, April). The impact of a buy local agriculture campaign on the South Carolina economy. Presentation at the $52^{\text {nd }}$ Southern Regional Science Association Annual Meeting, Arlington, Virginia. 
Johnson, T. G. (2012, August). Models for assessing regional economic impacts of agriculture and rural development efforts: Introduction. Presentation at Agricultural \& Applied Economics Association Community Economics Network Section Post-conference workshop: Models for assessing regional economic impacts of agriculture and rural development efforts, Seattle. Retrieved from http://aese.psu.edu/nercrd/ presentations/seattle-aee-2013

Lev, L., Brewer, L., \& Stephenson, G. (2003). Research brief: How do farmers' markets affect neighboring businesses? (Oregon Small Farms Technical Report No. 16). Corvallis, Oregon: Oregon State University Extension Service.

Low, S. A., \& Vogel, S. (2011). Direct and intermediated marketing of local foods in the United States (Economic Research Report No. ERR-128). Washington, D.C.: U.S. Department of Agriculture Economic Research Service. Retrieved from http://www.ers. usda.gov/publications/err-economic-researchreport/err128.aspx\#.UdYwiqxQCz8

Lyson, T. A., Gillespie Jr., G. W., \& Hilchey, D. (1995). Farmers markets and the local community: Bridging the formal and informal economy. American Journal of Alternative Agriculture, 10(3), 108-113. http://dx.doi.org/10.1017/S0889189300006251

McCarthy, R., \& Moon, J. R. (2012). The economic impact of farmers markets: A study of 9 markets in 3 major U.S. cities. New Orleans: Market Umbrella.

Miller, R. E., \& Blair, P. D. (2009). Input-Output Analysis: Foundations and Extensions (2nd ed.). New York: Cambridge University Press.

Myles, A., \& Hood, K. (2010). Economic impact of farmers' markets in Mississippi (Publication 2582). Mississippi State, Mississippi: Mississippi State University Extension Service. Retrieved from http://msucares.com/pubs/publications/ p2582.html

Otto, D. (2010). Consumers, vendors, and the economic importance of Iowa farmers' markets: An economic impact survey analysis. Ames, Iowa: Strategic Economics Group. Retrieved from http://www.agriculture. state.ia.us/Horticulture_and_FarmersMarkets/pdfs /FarmersMarketEIS2009.pdf
Pirog, R., \& O’Hara, J. K. (2013). Economic analysis of local and regional food systems: Taking stock and looking ahead. East Lansing, Michigan: Michigan State University Center for Regional Food Systems, and Washington, D.C.: Union of Concerned Scientists. Retrieved from http://foodsystems.msu.edu/ uploads/file/resources/econ-analysis-brief.pdf

Sadler, R. C., Clark, M. A. R., Gilliland, J. A. (2013). An economic impact comparative analysis of farmers' markets in Michigan and Ontario. Journal of Agriculture, Food Systems, and Community Development, 3(3), 61-81. http://dx.doi.org/10.5304/jafscd.2013.033.009

Schmit, T. M., Jablonski, B. B. R., \& Mansury, Y. (2013). Impacts of local food system activities by small direct-toconsumers producers in a regional economy: A case study from upstate NY [WP 2013-16]. Ithaca, New York: Cornell University Charles H. Dyson School of Applied Economics and Management. http://dyson.cornell.edu/research/researchpdf/ wp/2013/Cornell-Dyson-wp1316.pdf

Swenson, D. (2010). Selected measures of the economic values of increased fruit and vegetable production and consumption in the upper Midwest. Ames, Iowa: Leopold Center for Sustainable Agriculture.

The IMPLAN Group. (2013). Economic Impact Analysis: IMPLAN. Accessed May 28, 2013, from http://implan.com/V4/Index.php

Thilmany, D., Gunter, A., \& Tegegne, E. (2013, April). Toward a typology of economic impact and welfare analysis for local and regional food systems. Presentation at the $52^{\text {nd }}$ Southern Regional Science Association Annual Meeting, Arlington, Virginia.

Tootelian, D. H., Mikhailitchenko, A., \& Varshney, S. B. (2012). Can producing and marketing healthy foods create a healthy economy? Journal of Food Products Marketing, 18(3), 242-256. http://dx.doi.org/10.1080/10454446.2012.668376

Tuck, B., Haynes, M., King, R., \& Pesch, R. (2010). The economic impact of farm-to-school lunch programs: A central Minnesota example. St. Paul, Minnesota: University of Minnesota Extension. 